\title{
RPA1 Gene Mutation
}

National Cancer Institute

\section{Source}

National Cancer Institute. RPA1 Gene Mutation. NCI Thesaurus. Code C132007.

A change in the nucleotide sequence of the RPA1 gene. 